\title{
A new tool for the chemical genetic investigation of the Plasmodium falciparum Pfnek-2 NIMA-related kinase
}

\author{
Deborah F. Mitcheson ${ }^{1}$, Andrew R. Bottrill ${ }^{2}$, Katherine Carr' , Christopher R. Coxon ${ }^{3}$, Celine Cano 4 , \\ Bernard T. Golding ${ }^{4}$, Roger J. Griffin ${ }^{4}$, Andrew M. Fry ${ }^{1}$, Christian Doerig ${ }^{5}$, Richard Bayliss ${ }^{6}$ and Andrew B. Tobin ${ }^{7 *}$
}

\begin{abstract}
Background: Examining essential biochemical pathways in Plasmodium falciparum presents serious challenges, as standard molecular techniques such as siRNA cannot be employed in this organism, and generating gene knock-outs of essential proteins requires specialized conditional approaches. In the study of protein kinases, pharmacological inhibition presents a feasible alternative option. However, as in mammalian systems, inhibitors often lack the desired selectivity. Described here is a chemical genetic approach to selectively inhibit Pfnek-2 in P. falciparum, a member of the NIMA-related kinase family that is essential for completion of the sexual development of the parasite.

Results: Introduction of a valine to cysteine mutation at position 24 in the glycine rich loop of Pfnek-2 does not affect kinase activity but confers sensitivity to the protein kinase inhibitor 4-(6-ethynyl-9H-purin-2-ylamino) benzene sulfonamide (NCL-00016066). Using a combination of in vitro kinase assays and mass spectrometry, (including phosphoproteomics) the study shows that this compound acts as an irreversible inhibitor to the mutant Pfnek2 likely through a covalent link with the introduced cysteine residue. In particular, this was shown by analysis of total protein mass using mass spectrometry which showed a shift in molecular weight of the mutant kinase in the presence of the inhibitor to be precisely equivalent to the molecular weight of NCL-00016066. A similar molecular weight shift was not observed in the wild type kinase. Importantly, this inhibitor has little activity towards the wild type Pfnek-2 and, therefore, has all the properties of an effective chemical genetic tool that could be employed to determine the cellular targets for Pfnek-2.
\end{abstract}

Conclusions: Allelic replacement of wild-type Pfnek-2 with the mutated kinase will allow for targeted inhibition of Pfnek-2 with NCL-00016066 and hence pave the way for comparative studies aimed at understanding the biological role and transmission-blocking potential of Pfnek-2.

Keywords: Plasmodium falciparum, NIMA-related protein kinase (Nek), Covalent modification, Chemical genetics, Mass spectrometry

\section{Background}

Despite the efficacy of artemisinin-based combination therapy (ACT) in the treatment of malaria, an estimated 214 million cases and 438,000 malaria deaths occurred globally in 2015 [1]. Together with alarming recent reports of the emergence of resistance to ACT [2-4],

\footnotetext{
*Correspondence: tba@leicester.ac.uk

${ }^{7}$ Centre for Translational Pharmacology, Institute of Molecular Cell and Systems Biology, University of Glasgow, Glasgow G12 8QQ, UK Full list of author information is available at the end of the article
}

this highlights the urgent need for novel anti-malarial treatments.

Protein phosphorylation is known to play key roles in the progression of the Plasmodium life cycle through both the human host and the mosquito vector. Thirty-six of the approximately 90 kinases encoded in the parasite's genome appear to play essential roles in key parasite processes, including invasion, proliferation and cyto-adherence [5], suggesting that targeting these protein kinases has therapeutic value [6]. Despite this, and the fact that 
protein kinases have proven successful targets in a number of human diseases, most notably cancer [7], no protein kinase inhibitors have yet reached the clinic for the treatment of malaria.

Amongst the protein kinases that play essential roles in the parasite's life cycle are Pfnek-1 and Pfnek-2, members of the NIMA-related protein kinase family (which consists in total of four members Pfnek1-4) [8-12]. Whereas Pfnek-1 is considered essential for the completion of the erythrocytic asexual cycle [10,12], Pfnek-2 is dispensable for asexual proliferation but essential for the completion of sexual development of the parasite in the mosquito vector [9]. It therefore represents a potential target for transmission-blocking drugs. Phylogenetic analysis of Plasmodium Neks [8] indicates that Pfnek- 2 and Pfnek-4 form a cluster that is loosely associated with human Hsnek4.

In humans, there are 11 members of the Nek family with various roles in several processes. The involvement of human Hsnek2 in cell cycle regulation events, including centrosome disjunction, spindle assembly and the DNA damage response [13], has suggested that inhibitors to Hsnek2 might have clinical efficacy in the treatment of cancer [14-19]. There have been considerable efforts to generate inhibitors to Hsnek2 through the implementation of structure-based design to exploit unique structural features of the ATP binding pocket [20-23]. This has lead to the development of a compound, 4-(6-ethynyl-9H-purin-2-ylamino) benzene sulfonamide (NCL00016066), that acts as an irreversible inhibitor of human Hsnek2. Structural studies have established that the inhibitory activity of NCL-00016066 results from the presence of the ethynyl group which forms an irreversible covalent link with cysteine-22 in the glycine rich loop [24].

Although phylogenetic studies have indicated that Hsnek2 and Pfnek-2 are not orthologues [8] they do however share several common features, including a large methionine gatekeeper residue, a bulky phenylalanine which restricts access for ATP-competitive protein kinase inhibitors and the conserved DaFG........A/SPE sequence within the activation loop. One difference however is that parasite Pfneks lack the cysteine in the glycine rich loop with which NCL-00016066 forms a covalent linkage in Hsnek2. This position in Pfnek-2 (amino acid 24) is occupied by a valine. It can, therefore, be predicted that in the absence of a cysteine in position 24, NCL-00016066 would act as a very weak inhibitor of Pfnek-2 activity. Furthermore, by replacing valine 24 (Val24) in Pfnek-2 with a cysteine, a mutant kinase would be generated that would be sensitive to NCL-00016066 inhibition. The final prediction would be that in the cysteine mutant, NCL00016066 would act in an irreversible manner by forming a covalent link with the substituted cysteine.
The data presented here show that these predictions are correct and that by substituting Val24 for cysteine in Pfnek-2, it is possible to generate a chemical genetic tool that could be used to dissect the in vivo function of Pfnek-2.

\section{Methods \\ Materials}

Unless otherwise stated all biochemicals and reagents were from Sigma-Aldrich.

\section{Parasite culture and treatment with NCL-00016066} Plasmodium falciparum blood stage 3D7 (wild type) parasites were grown (as previously described [25]) in complete RPMI 1640 medium (RPMI 1640 medium with $2 \mathrm{mM}$ L-glutamine, $25 \mathrm{mM}$ HEPES, $2 \mathrm{~g} / \mathrm{l} \mathrm{NaHCO}_{3}$, $27.2 \mathrm{mg} / \mathrm{l}$ hypoxanthine and $0.5 \%$ Albumax II, $\mathrm{pH} 7.4$ ) using $\mathrm{O}^{+}$human red blood cells at $37{ }^{\circ} \mathrm{C}$ in an incubator with $5 \% \mathrm{CO}_{2}, 5 \% \mathrm{O}_{2}$ and $90 \% \mathrm{~N}_{2}$. Sorbitol treatment was used to synchronize the parasites [26]: parasites were treated with $5 \%$ sorbitol for $20 \mathrm{~min}$ at room temperature to lyse trophozoite and schizont stage parasites. Dead parasites were removed by two washes with incomplete RPMI medium (RPMI 1640 medium with $2 \mathrm{mM}$ L-glutamine, $25 \mathrm{mM}$ HEPES, $\mathrm{pH}$ 7.4). Following sorbitol treatment parasites were transferred to complete RPMI 1640 medium.

To determine the viability of parasites cultures that had reached the trophozoite stage, they were diluted to $0.3 \%$ parasitaemia and $2 \%$ haematocrit and treated with increasing concentrations of NCL-00016066 in a 96-well round bottom plate (Corning) and incubated for $72 \mathrm{~h}$ in an incubator with $5 \% \mathrm{CO}_{2}, 5 \% \mathrm{O}_{2}$ and $90 \% \mathrm{~N}_{2}$. Several wells were treated with either $10 \%$ DMSO or $20 \mu \mathrm{M}$ chloroquine as controls. They were then placed in a $-80{ }^{\circ} \mathrm{C}$ freezer prior to lactate dehydrogenase (LDH) and SYBR Green I assays.

\section{SYBR Green I assay}

Frozen plates were thawed for approximately $4 \mathrm{~h}$ at room temperature and $100 \mu \mathrm{l}$ of SYBR Green I reaction buffer (20 mM Tris, 5 mM EDTA, pH 7.5, 0.08\% Triton $\mathrm{X}-100,0.008 \%$ saponin and $0.1 \mu \mathrm{l} / \mathrm{ml}$ SYBR Green I) was added to each well on the plate. The plate was shaken for $10 \mathrm{~min}$ to ensure mixing and incubated for $1 \mathrm{~h}$ at room temperature in the dark. The fluorescence was read using a CLARIOstar plate reader. (BMG Labtech $\mathrm{GmbH}$, Germany).

\section{Lactate dehydrogenase (LDH) assay}

Frozen plates were thawed for approximately $4 \mathrm{~h}$ at room temperature and $150 \mu \mathrm{l}$ of $\mathrm{LDH}$ reaction buffer [100 mM Tris- $\mathrm{HCl}, \mathrm{pH}$ 8.0, $150 \mathrm{mM}$ sodium lactate, 
$150 \mu \mathrm{M}$ APAD (3-Acetylpyridine adenine dinucleotide), $180 \mu \mathrm{M}$ Nitrotetrazolium Blue Chloride, 0.7\% Tween-20 and diaphorase ( 0.3 units/assay)] was added to each well on the plate. The plate was shaken for $10 \mathrm{~min}$ to ensure mixing and the absorbance at $595 \mathrm{~nm}$ was obtained using a CLARIOstar plate reader. (BMG Labtech GmBH, Germany).

\section{Pfnek-2 plasmid design}

The synthetic full-length coding sequence for Pfnek-2 (PlasmoDB identifier PF3D7_0525900) was purchased (with codon optimization for Escherichia coli expression) from GeneArt ${ }^{\mathrm{TM}}$ Life Technologies. The codon optimized DNA sequence was as follows (the codon encoding V24 is highlighted in bold); ATGAGCAAACCGAAAATGATCGGTCCGTATGAAGTTGTGAAAAGCATTGGTCGTGGTAGCTTTGGTATTGTTACCGCAGTTAAAGATGAAAATGAAAAAATCTTTGTGAT TAA AGA ACTGGATATTAGCTGCATGAATAACAAAGAAAAAATGAATGTGGTGAATGAAAT TCGTGCCCTGAT TAAAATGAGCGTGCATCCGTTTATTGTGCGCTATAAAGAAGCCTTTGTTGAAGAT TGCGTTCTGTATGTTGCGATGGATTATTGCATTAATGGTGATCTGGGCAAAGTGATCAAAAAACACAAAGAACTGGAAACCCCGATTCCTGAGAAAAAAATCAAACGTTGGCTGCTGCAGATTATTATGGCCATCAAATTCATTCATGATAAAAAACTGATCCATCGTGATCTGAAATGCAATAACATCT TCCTGGATGAAAAAGAACGTGCCAAAATTGGTGATTTTGGTCTGGCCAAATTTATCGA ACA G A C A G A A C A GACCA ATACC CTGTGTGGCACCATTGGTTATATGGCACCGGAAATTTGCAAAAATATCAATTACAGCTTCCCTGCCGATATTTGGAGCCTGGGTATTATTCTGTATGAACTGATTAGCCTGAAACCGCCTTTTAAAAGCAATAACAGCAATATGCTGAGCGTGGCCCAGAAAATTTGTGAAGATGAACCGGATCCGCTGCCGGATAGCTTTAGCAAAGATCTGATTAATCTGTGCTATTGGATGCTGAAAAAAGATTGGAAAGATCGTCCGACCATCTACGATATTATCAGCACCGATTATATCCAGGATGAACTGCAGCTGTTTAAACGTGAAATGCTGCAAGAACGTAACAGCCAGATT.

The codon optimized sequence was cloned into a pET30a vector using NdeI and XhoI sites and a stop codon was added by site directed mutagenesis. The final construct used for protein expression contained an N-terminal His tag and a cleavable Tev sequence followed by the full length Pfnek-2 sequence.

\section{Cloning of Pfnek-2 and site-directed mutagenesis}

The plasmid described above encoding wild type PfNek-2 was used as a template to generate Pfnek-2
V24C by site directed mutagenesis. The following primers were used forward (5'-gcattggtcgtggtagctttggtatttgtaccgcagttaaaga- $3^{\prime}$ ) and reverse (5'-tctttaactgcggtacaaataccaaagctaccacgaccaatgc-3').

\section{Bacterial protein expression}

Full-length Pfnek-2 as a 6-HIS-tagged protein was expressed in E. coli BL21-Codon Plus(DE3)-RIPL strain (Agilent Technologies). Cells were treated with $1 \mathrm{mM}$ IPTG when the optical density of the cell culture at $600 \mathrm{~nm}$ reached 0.6 , and protein expression was induced overnight at $18{ }^{\circ} \mathrm{C}$. For purification, cells were lysed in buffer [ $50 \mathrm{mM}$ bicine, $\mathrm{pH} 8.0,150 \mathrm{mM} \mathrm{NaCl}, 20 \mathrm{mM}$ Imidazole, $1 \%$ glycerol, $1 \mathrm{mM}$ DTT, Protease Inhibitor Cocktail (Roche)] [1 tablet per $10 \mathrm{ml}$ (cOmplete ${ }^{\mathrm{TM}}$ ULTRA Tablets by Roche)] by sonication for 10 cycles of $10 \mathrm{~s}$ bursts at $10 \mathrm{~mA}$ with a $30 \mathrm{~s}$ rest between each cycle. During sonication the cells were kept on ice. Lysates were then centrifuged at $20,000 \mathrm{~g}$ for $30 \mathrm{~min}$. The resulting supernatants were loaded onto a $0.5 \mathrm{ml}$ pre-equilibrated Ni-NTA Superflow resin (Qiagen) column, washed with buffer (50 mM bicine, pH 8.0, $150 \mathrm{mM} \mathrm{NaCl}, 20 \mathrm{mM}$ Imidazole, $1 \%$ glycerol and $1 \mathrm{mM}$ DTT) and proteins were eluted with the same buffer containing $400 \mathrm{mM}$ Imidazole. Eluted proteins were dialysed against $50 \mathrm{mM}$ bicine, $\mathrm{pH} 8.0,150 \mathrm{mM} \mathrm{NaCl}, 1 \%$ glycerol and $1 \mathrm{mM}$ DTT at $4{ }^{\circ} \mathrm{C}$ overnight. Dialysed Pfnek-2 protein was aliquoted and stored at $-80^{\circ} \mathrm{C}$.

\section{In vitro Pfnek-2 kinase assay}

Recombinant His-tagged WT or V24C mutant Pfnek-2 were assayed for protein kinase activity using myelin basic protein (MBP) as a substrate. $1.8 \mu \mathrm{g}$ of either Pfnek-2 WT or Pfnek-2 V24C were pre-incubated at room temperature for $40 \mathrm{~min}$ with/without NCL$00016066(1,10$ or $20 \mu \mathrm{M})$ in Pfnek-2 buffer $(10 \mathrm{mM}$ bicine, $\mathrm{pH}$ 8.0, $40 \mathrm{mM} \mathrm{NaCl}, 1 \%$ glycerol, $10 \mathrm{mM} \mathrm{MgCl}$, $4 \mathrm{mM}$ imidazole, $1 \mathrm{mM}$ DTT) in the presence of $5 \mu \mathrm{g}$ MBP. The reaction was started by the addition of $5 \mu \mathrm{l}$ $200 \mu \mathrm{M} \mathrm{ATP} /{ }^{32} \mathrm{P}$-ATP $(0.0185 \mathrm{MBq}$ per reaction) - total volume $20 \mu \mathrm{l}$. Following incubation of $30 \mathrm{~min}$ at $37^{\circ} \mathrm{C}$, the reactions were stopped by adding $10 \mu \mathrm{l} 2 \times$ Laemmli buffer and proteins were separated by SDS-PAGE on $12 \%$ gels and stained with Coomassie blue. Dried gels were exposed to X-ray film.

\section{NCL-00016066 compound}

The human Nek2 inhibitor, NCL-00016066 (gift from Professor Roger Griffin, University of Newcastle) was dissolved in DMSO to $10 \mathrm{mM}$ and frozen in aliquots of $10 \mu \mathrm{l}$ at $-80{ }^{\circ} \mathrm{C}$. These aliquots were kept in the dark and a fresh aliquot diluted prior to each kinase assay. All samples in each kinase assay were pre-incubated with 
NCL-00016066 for $40 \mathrm{~min}$ at room temperature and the reaction initiated by the addition of $\mathrm{ATP} /{ }^{32} \mathrm{P}$-ATP as previously described above.

\section{Immobilising Pfnek-2 (wild type) and Pfnek-2 (V24C) on Ni-NTA Superflow Beads-pre-incubation with inhibitor NCL-00016066}

Recombinant Pfnek-2 wild type and Pfnek-2 V24C were purified as previously described and incubated (1:1) without/with $20 \mu \mathrm{M}$ NCL-00016066 diluted in $10 \mathrm{mM}$ bicine, $\mathrm{pH}$ 8.0, $40 \mathrm{mM} \mathrm{NaCl}, 10 \mathrm{mM} \mathrm{MgCl}$, $1 \%$ glycerol, $4 \mathrm{mM}$ imidazole, $1 \mathrm{mM}$ DTT at room temperature for $30 \mathrm{~min}$. $50 \mu \mathrm{l} \mathrm{Ni-NTA} \mathrm{Superflow} \mathrm{resin} \mathrm{(Qiagen)}$ was added and the samples made up to $500 \mu \mathrm{l}$ in buffer (10 mM bicine, $\mathrm{pH} 8.0,40 \mathrm{mM} \mathrm{NaCl}, 10 \mathrm{mM} \mathrm{MgCl}_{2}$, $1 \%$ glycerol, $4 \mathrm{mM}$ imidazole, $1 \mathrm{mM}$ DTT) and rotated for $1 \mathrm{~h}$ at room temperature. The beads were washed $3 \times$ in $500 \mu \mathrm{l}$ buffer for 5 min rotation and supernatants discarded. The in vitro kinase assay protocol described above was followed and the enzyme immobilized on beads (washed and supernatant removed) is assumed to be $5 \mu \mathrm{l}$ for the purpose of the kinase assay. During incubation at $37^{\circ} \mathrm{C}$ the beads were gently re-suspended every $10 \mathrm{~min}$.

\section{Preparation of samples for mass spectroscopy}

Recombinant Pfnek-2 wild type and Pfnek-2 V24C were purified as previously described except glycerol was absent from all buffers. The absence of glycerol had no effect on the activity of the enzyme and was only added to previous preparations to stabilize the enzyme. Glycerol however interferes with the mass spectrometry and so was omitted here. Both wild type and mutant (V24C) Pfnek-2 were incubated (1:1) without/with $100 \mu \mathrm{M}$ NCL-00016066 diluted in buffer (10 mM bicine, $\mathrm{pH}$ 8.0, $40 \mathrm{mM} \mathrm{NaCl}, 10 \mathrm{mM} \mathrm{MgCl}$, $4 \mathrm{mM}$ imidazole, $1 \mathrm{mM}$ DTT) at room temperature prior to mass spectrometry analysis.

\section{Mass spectrometry-identification of putative covalent bonding of NCL-00016066 to Pfnek-2}

LC-MS was carried out using an RSLCnano HPLC system (Thermo Scientific) coupled to an LTQ-OrbitrapVelos mass spectrometer (Thermo Scientific). Samples were loaded at $0.1 \mathrm{ml} / \mathrm{min}$ onto a Vydac C8 $5 \mu \mathrm{m} 250$ $\mathrm{mm} \times 1 \mathrm{~mm}$ I.D. reverse phase column (Grace Davison). The protein was desalted for $10 \mathrm{~min}$ in the loading buffer ( $0.1 \%$ formic acid) before elution using a 10 min linear gradient from 3 to $96 \%$ B $(80 \%$ acetonitrile/ $0.1 \%$ formic acid). The output of the column was sprayed directly into the H-ESI2 electrospray ion source of the mass spectrometer maintained at $5 \mathrm{kV}$. The ion trap was set to acquire 10 microscans over the $m / z$ range $800-1200 \mathrm{Da}$ in positive ion mode. The maximum injection time for MS was $50 \mathrm{~ms}$ and the AGC target setting was 3e4. Protein charge-state distributions were viewed using the

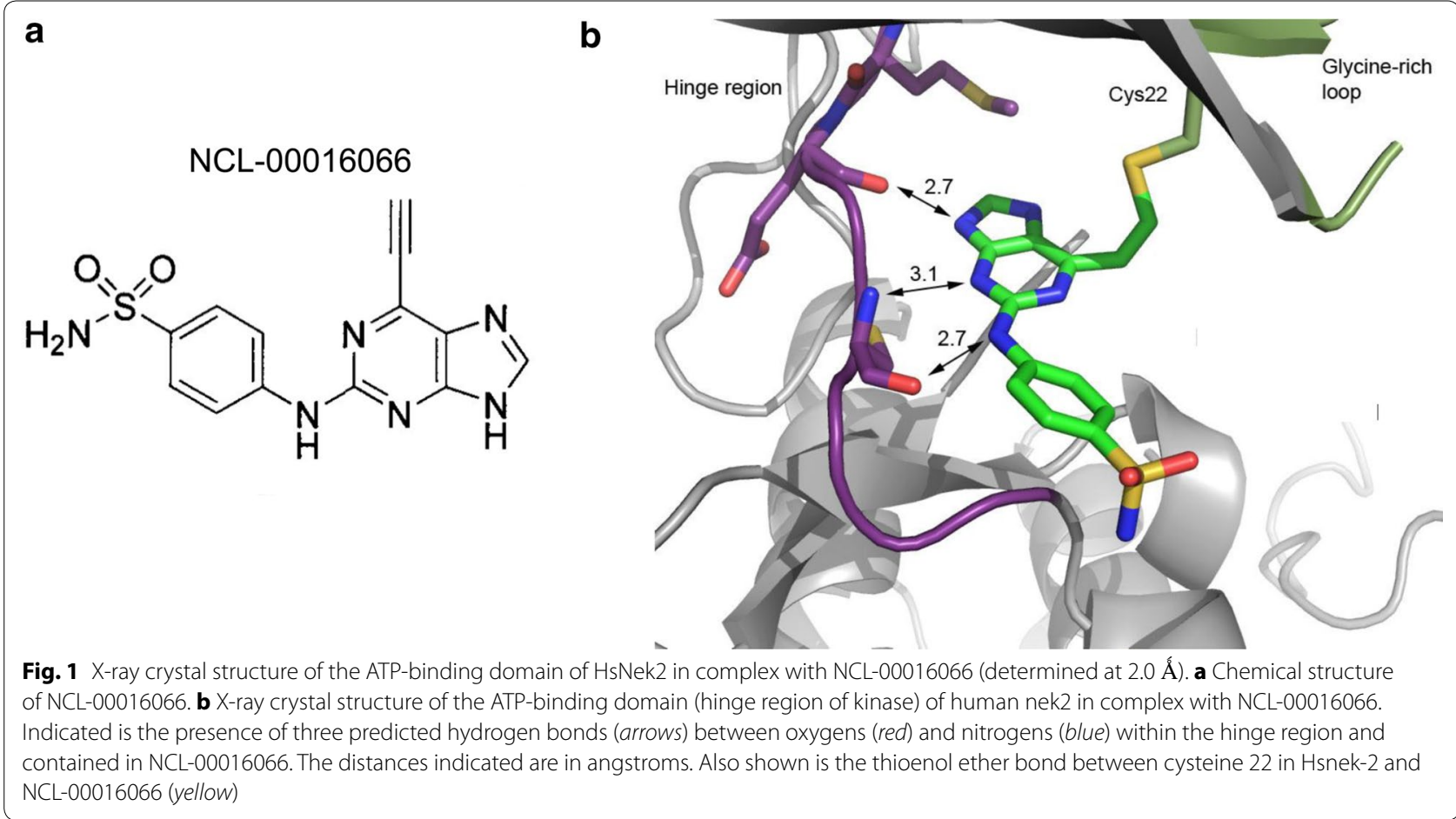


Xcalibur program (version 2.1.0.1139, Thermo Scientific) and molecular weight calculations made using ESIprot [27].

\section{Mass spectrometry analysis of Pfnek-2 autophosphorylation}

Recombinant Pfnek-2 (4 $\mu \mathrm{l}$ of $13 \mathrm{mg} / \mathrm{ml}$ stock solution of enzyme) was incubated with/without $1 \mathrm{mM}$ ATP in Pfnek-2 buffer (10 mM bicine, $\mathrm{pH}$ 8.0, $40 \mathrm{mM} \mathrm{NaCl}, 1 \%$ glycerol, $10 \mathrm{mM} \mathrm{MgCl} 2,4 \mathrm{mM}$ imidazole, $1 \mathrm{mM}$ DTT) for $30 \mathrm{~min}$ at $37^{\circ} \mathrm{C}$. The reaction was stopped by adding $10 \mu \mathrm{l} 2 \times$ Laemmli buffer and proteins were separated by SDS-PAGE on a $12 \%$ gel. The dye front was removed and the gel placed in fixing solution [7\% glacial acetic acid in $40 \%(\mathrm{v} / \mathrm{v})$ methanol] for $1 \mathrm{~h}$. The gel was stained with four parts colloidal blue to one part methanol and destained with $10 \%$ acetic acid in $25 \%(\mathrm{v} / \mathrm{v})$. Protein bands were excised from the gel and cut into small pieces and washed three times with $200 \mu \mathrm{l}$ of buffer B [ $20 \mathrm{ml} 400 \mathrm{mM}$ ammonium bicarbonate $(3.16 \mathrm{~g} / 100 \mathrm{ml})$ with $100 \%$ acetonitrile in ratio 1:1]. The gel pieces were then washed twice with $200 \mu \mathrm{l}$ acetonitrile (100\%) and gel pieces air dried.

The gel fragments were then incubated for $30 \mathrm{~min}$ at $60{ }^{\circ} \mathrm{C}$ in $100 \mu \mathrm{l} 10 \mathrm{mM}$ DTT in $50 \mathrm{mM}$ TEAB buffer, $\mathrm{pH}$ 8.5. The liquid was removed and the fragments incubated in $100 \mu \mathrm{l} 100 \mathrm{mM}$ iodoacetamide in $50 \mathrm{mM}$ TEAB buffer

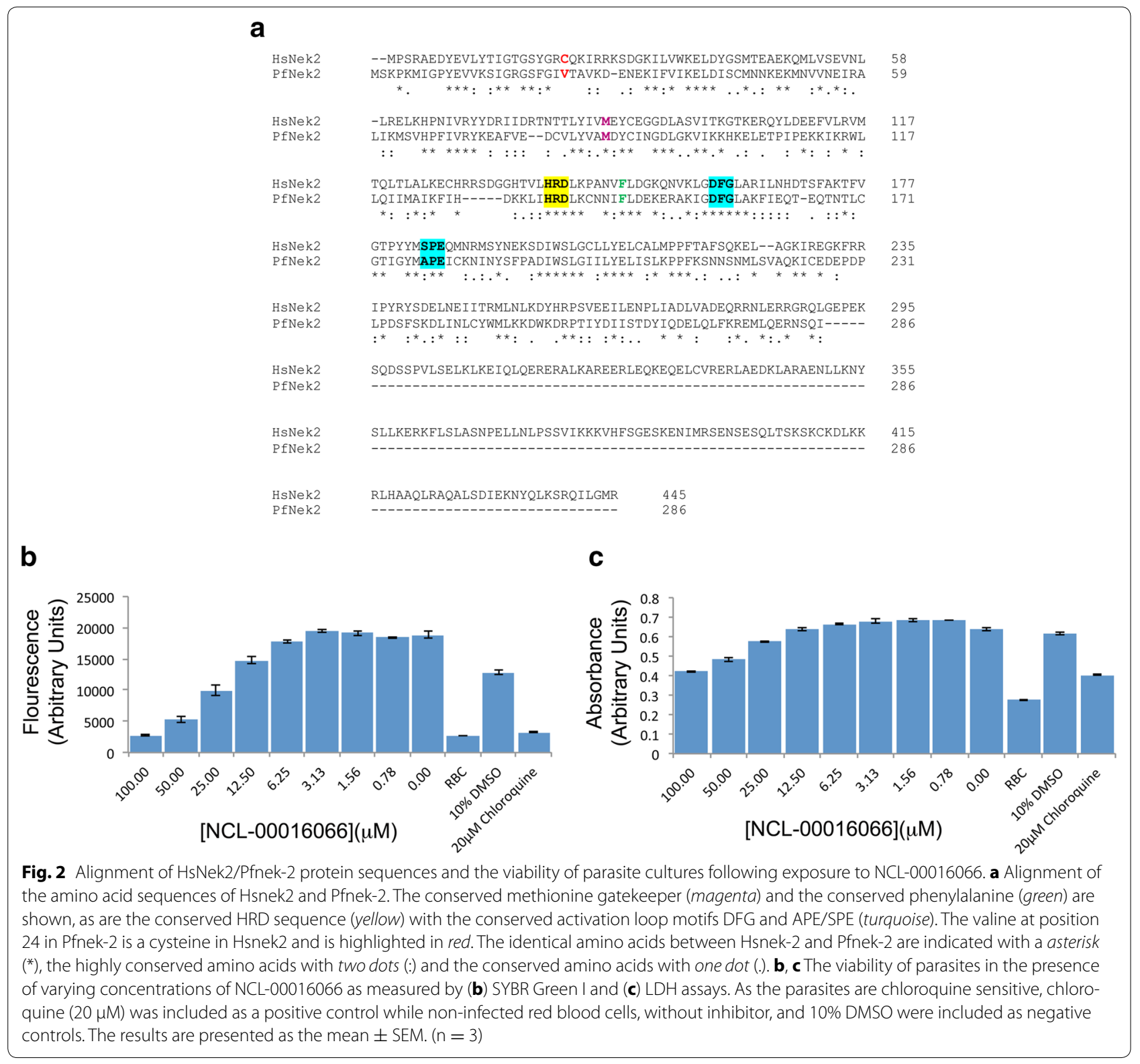


for $30 \mathrm{~min}$ at room temperature in the dark. The fragments were washed twice in buffer B for 20 min, washed briefly in acetonitrile $(100 \%)$ followed by a further addition of acetonitrile for $10 \mathrm{~min}$ at room temperature followed by aspiration of the fluid and air drying. Trypsin solution $(1 \mu \mathrm{g}$ in $50 \mu \mathrm{l}$ of $50 \mathrm{mM}$ TEAB buffer per sample) was added and incubated at $37{ }^{\circ} \mathrm{C}$ overnight. The gel pieces were washed in $50 \mathrm{mM}$ TEAB buffer for 5-10 min on a rotating platform. The digests and washes were combined and dried completely in a SpeedVac. The samples were then enriched for phosphopeptides as described below.

\section{IMAC enrichment of phosphopeptides for mass spectrometry}

PHOS-Select iron affinity gel (Sigma) was equilibrated with $5 \times 1 \mathrm{ml} \mathrm{IMAC} \mathrm{load/wash} \mathrm{buffer}[0.25 \mathrm{M}$ acetic acid, 30\% (v/v) acetonitrile]. $500 \mu \mathrm{l}$ IMAC load/wash buffer was added to completely dry samples and $50 \mu \mathrm{l}$ of $50 \%$ PHOS-Select slurry was added followed by rotating at room temperature for $1 \mathrm{~h}$. Following incubation with IMAC beads, the samples were transferred onto Mobicol 'Classic' spin columns (2B Scientific Ltd), centrifuged for $30 \mathrm{~s}$ at $1000 \times g$, and the flow-through (unbound peptides) collected and frozen. The IMAC beads were washed twice with $200 \mu \mathrm{l}$ of IMAC load/wash buffer, once with $200 \mu \mathrm{l}$ of HPLC grade water and eluted twice with $100 \mu \mathrm{l}$ of solution containing $22 \mu \mathrm{l}$ ammonia solution (Fisher Chemical, 35\% stock), $300 \mu \mathrm{l}$ acetonitrile to a total volume of $1 \mathrm{ml}$ with HPLC grade water. Eluates were concentrated to a small volume $(15-20 \mu \mathrm{l})$ in a Speedvac centrifuge and submitted for mass spectrometry analysis.

\section{Mass spectroscopy and data processing-identification of potential autophosphorylation sites}

This was carried out as previously described [28] with one difference in that peptides were eluted from a reversephase PicoFrit capillary column $(75 \mu \mathrm{m}$ i.d. $\times 400 \mathrm{~mm})$ over a period of $2 \mathrm{~h}$.

\section{Results}

\section{Characterization of Pfnek-2 and Pfnek-2 V24C mutant} kinases

The compound NCL-00016066 (Fig. 1a) was originally developed as an inhibitor to human Hsnek2 [24]. A crystal structure of NCL-00016066 in complex with Hsnek2 was obtained, and confirmed that the inhibitor formed a covalent linkage with Cys22 in the glycine rich loop through the ethynyl moiety of NCL-00016066 (Fig. 1b). A crystal structure for Pfnek-2 is not currently available however amino acid sequence alignment of Hsnek2 with Pfnek-2 revealed that there are no cysteine residues within the glycine rich loop of Pfnek-2 (Fig. 2a); the equivalent position of Hsnek2 Cys22, in Pfnek-2, is occupied by Val24 (Fig. 2a). This would indicate that the parasiticidal activity of NCL-0016066 would be very low, which was indeed found to be the case with $\mathrm{EC}_{50}$ values of $23.95 \pm 2.50$ and $35.63 \pm 3.03 \mu \mathrm{M}$ as measured by SYBR Green I and LDH parasite death assays, respectively (Fig. 2b, c). Substituting Pfnek-2 Val24 with a cysteine created a mutant, Pfnek-2(V24C), that could be expressed in E. coli and affinity purified on a Ni-NTA chromatography column through a His-tag engineered into the N-terminus of the kinase. Purified Pfnek-2 and Pfnek-2(V24C) were resolved by SDS PAGE and appeared as a single band at approximately $38 \mathrm{kDa}$ (Fig. 3a). Enzymatic activity of Pfnek-2 was assayed in in vitro kinase assays using $\alpha$-casein or myelin basic protein (MBP) as exogenous substrate. Both wild type and mutant enzymes favoured MBP as a substrate (Fig. 3b) and appeared to display similar kinase activities. Subsequent experiments therefore used MBP as a substrate.

\section{Effect of NCL-00016066 on kinase activity}

Having established the activity of the purified wild type and mutant kinases, we next tested the ability of NCL00016066 to inhibit kinase activity. Purified kinases were incubated with MBP in the presence of 10 or $1 \mu \mathrm{M}$ NCL-00016066 (Fig. 3a-g). In these experiments NCL00016066 did not significantly affect the activity of wildtype Pfnek-2 (Fig. 4a-g). In contrast, NCL-00016066

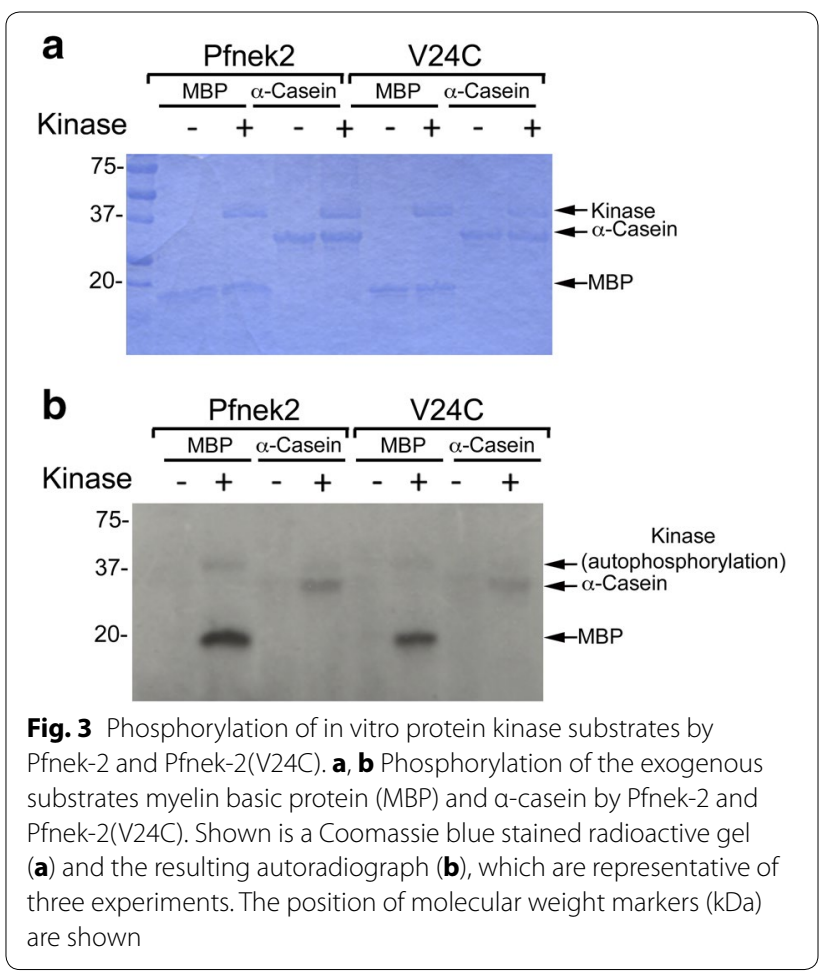



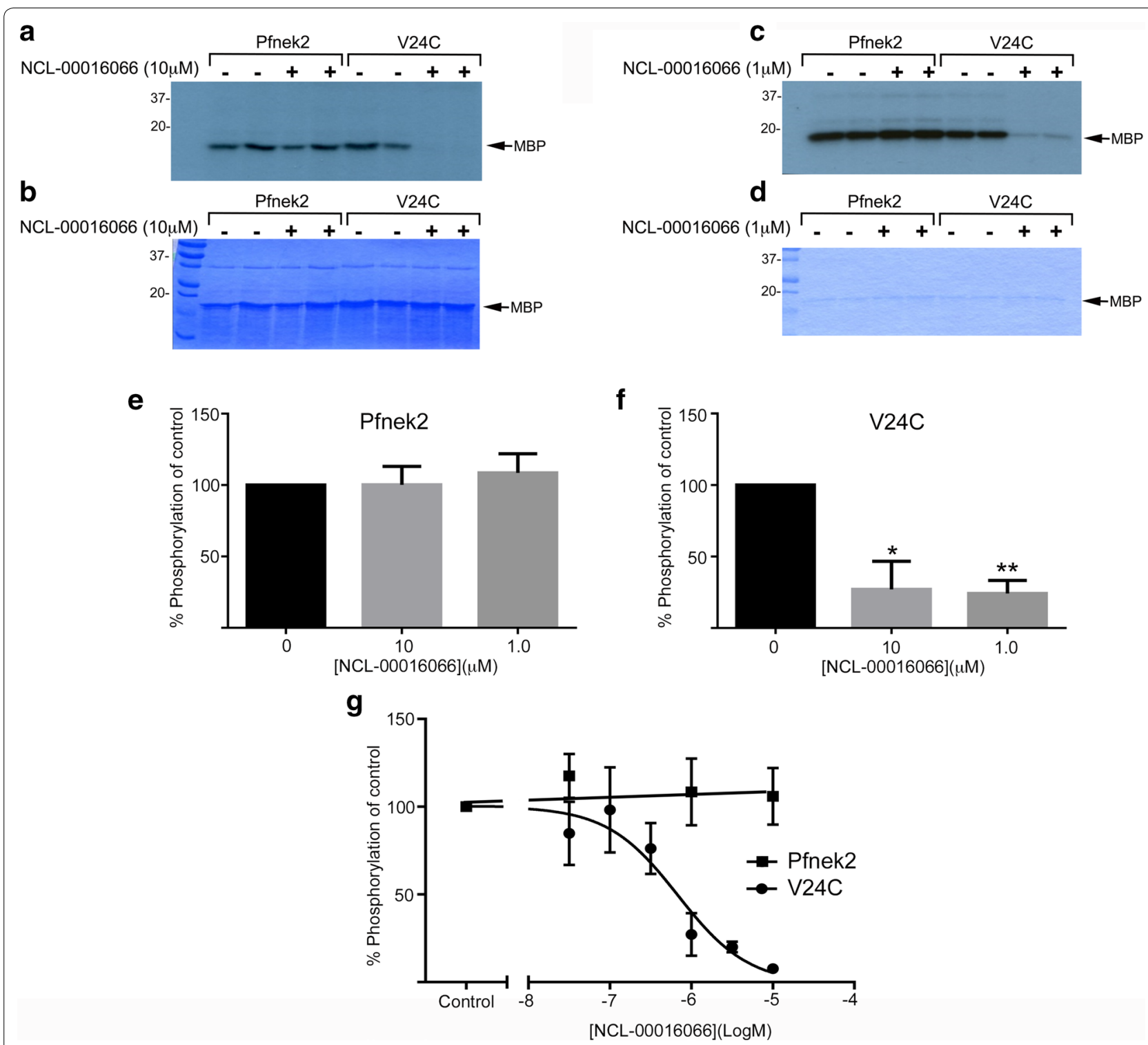

Fig. 4 Inhibition of Pfnek-2 and Pfnek-2(V24C) kinase activity by NCL-00016066. a, b Representative experiment showing the effect of NCL$00016066(10 \mu \mathrm{M})$ on the activity of Pfnek-2 and Pfnek-2(V24C). Shown is the autoradiograph (a) and Coomassie blue stained radioactive gel (b). c, d Same as (a, b) except the concentration of NCL-00016066 is 1 MM. The position of molecular weight markers (kDa) are shown. e, f Quantification of the experiments shown in $(\mathbf{a}-\mathbf{d})$. Data shown is the mean $\pm S E M ; n=3$. Data analysed using Students paired $t$ test ${ }^{*} p \leq 0.05$. $\mathbf{g}$ Concentrationresponse curve for the activity of NCL-00016066 against Pfnek-2 and Pfnek-2(V24C). Data shown is the mean \pm SEM; $n=3$. Data analysed using students paired t-test ${ }^{*} p \leq 0.05$

acted in a dose-dependent manner to inhibit the activity of Pfnek-2(V24C), with an $\mathrm{IC}_{50}$ value of $501 \mathrm{nM}\left[\mathrm{pIC} \mathrm{I}_{50}\right.$ (M) value, $6.30 \pm 0.25(\mathrm{n}=3)$ ] (Fig. 4c, d, f, g).

In order to investigate the mechanism of the inhibition of Pfnek-2(V24C) by NCL-00016066, the mutant kinase was pre-incubated with NCL-00016066 $(20 \mu \mathrm{M})$ prior to immobilization on Ni-NTA beads, and unbound inhibitor were removed by extensive washing. As a control, Pfnek-2 was similarly incubated with high concentrations of NCL-00016066 $(20 \mu \mathrm{M})$, which gave partial inhibition of kinase activity, which was reversed following washout (Fig. 5a). In contrast, NCL-00016066 $(20 \mu \mathrm{M})$ completely inhibited the activity of Pfnek-2(V24C) (Fig. 5b, c) in a manner that was not reversed by the washout procedure (Fig. 5b, c). These data indicated that Pfnek-2(V24C) was sensitive to NCL-00016066 inhibition and that inhibition of the mutant kinase by NCL-00016066 was irreversible (Fig. 5b, c). 


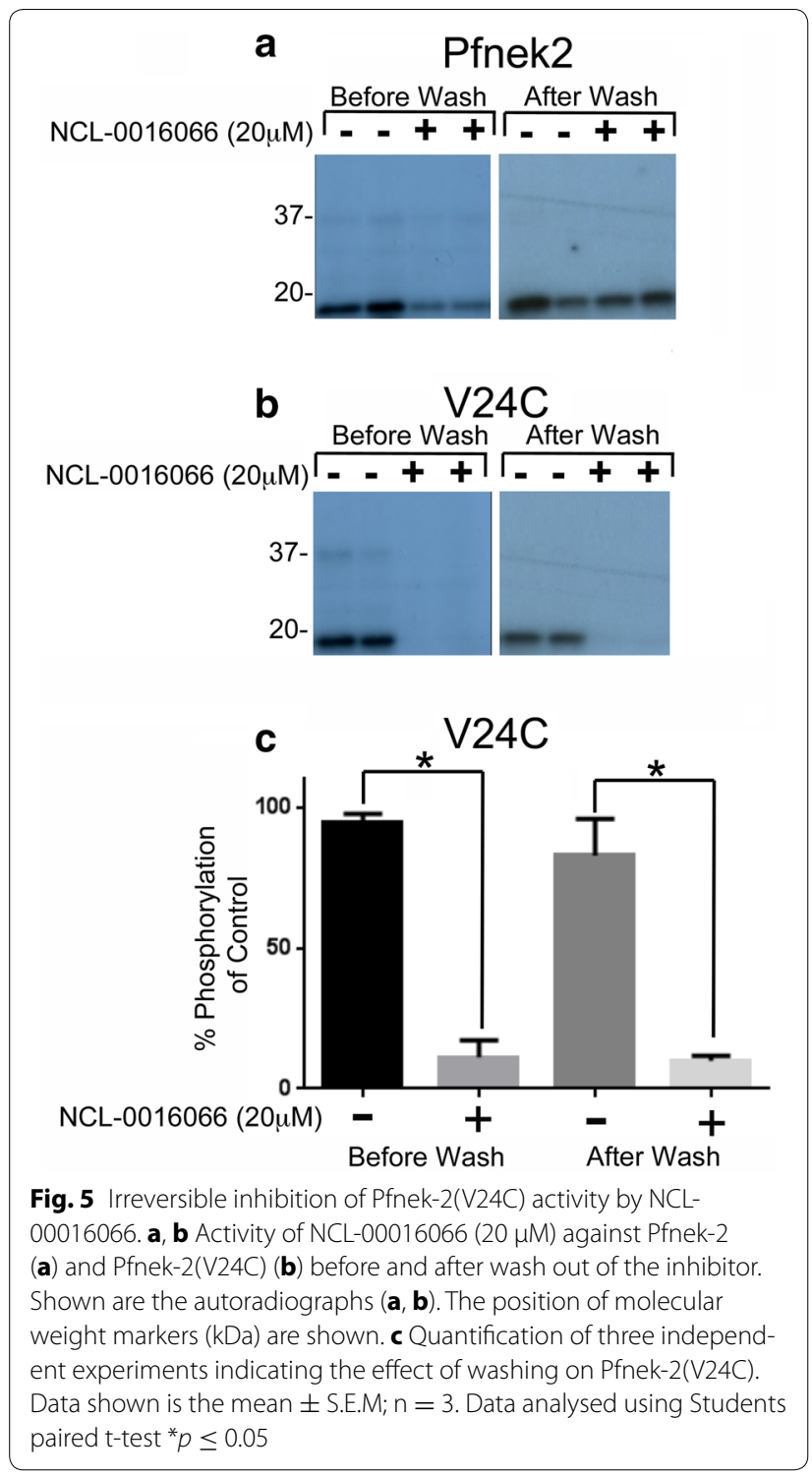

\section{Establishing the nature of the inhibition of the Pfnek-2(V24C) mutant}

In an effort to further characterize the nature of the inhibition of the mutant Pfnek-2 with NCL-00016066, wild type Pfnek-2 or Pfnek-2(V24C) were pre-incubated with or without $100 \mu \mathrm{M}$ NCL-00016066 and the intact protein subjected to analysis by mass spectrometry.

Pfnek-2 without inhibitor (black trace Fig. 6a; Table 1) showed charge state distributions containing 4-8 peaks that corresponded to different phosphorylation states. The addition of NCL-00016066 did not change the $\mathrm{m} / \mathrm{z}$ ratio of Pfnek-2 (red trace Fig. 6a; Table 1). In contrast, Pfnek-2(V24C) showed a clear shift in the $m / z$ ratio upon addition of NCL-00016066 (Fig. 6b; Table 1). The shift corresponded to a molecular weight change of $315.03 \pm 0.53 \mathrm{Da}$ which is the mass of NCL-00016066

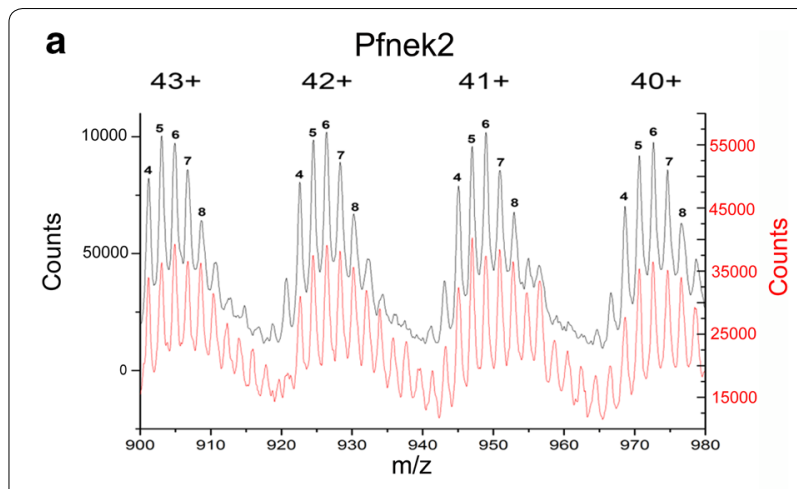

b

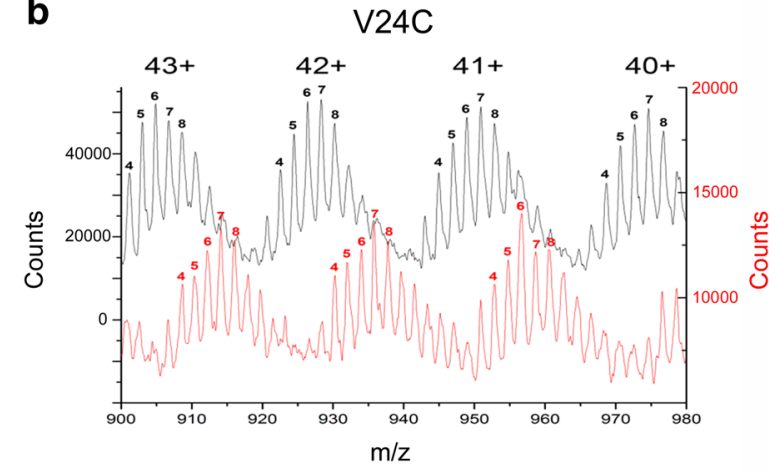

Key

$$
\text { - Without NCL-00016066 }
$$$$
\text { - With NCL-00016066 }
$$

Fig. 6 Shift in molecular weight of Pfnek-2 V24C as determined by mass spectroscopy. Pfnek-2 wild-type without (black trace) and with (red trace) NCL-00016066 a show no differences in peaks of the mass to charge ratios $(\mathrm{m} / \mathrm{z}$ ) for any particular charge state and number of phosphate groups (Table 1). In contrast when the mutant is incubated with inhibitor (b), there is a shift to the right (red trace) compared to without inhibitor (black trace) indicative of an increase in mass of $315.03 \pm 0.53 \mathrm{Da}$ - the approximate weight of the inhibitor confirming covalent bonding of the inhibitor to cysteine 22. For the purposes of clarity, in each panel the red trace is shifted vertically with respect to the black trace

(Table 1). This strongly suggests a covalent linkage of NCL-00016066 with the mutant kinase.

Table 1 shows the measured mass of the intact kinase $[\mathrm{MW}(\mathrm{Da})]$ and standard deviation, the predicted molecular weight for each charge state distributions (Predicted $M W)$, the number of phosphate groups ( $\mathrm{M}+$ Phospho), and the difference between the predicted and measured molecular weight $[\mathrm{D}(\mathrm{Da})]$. The values highlighted in red indicate the difference in molecular weight of the mutant kinase in the presence of NCL-00016066 where the $\Delta(\mathrm{Da})$ value approximates to the molecular weight of the inhibitor.

\section{Autophosphorylation of Pfnek-2}

Mass spectrometry analysis of the intact protein as described above indicated that Pfnek-2 undergoes 
Table 1 Molecular mass of Pfnek-2, Pfnek-2(V24C) and NCL-00016066

\begin{tabular}{|c|c|c|c|c|c|c|c|c|c|c|c|}
\hline \multirow{2}{*}{ M+ \#phospho } & \multicolumn{7}{|c|}{ Charge state distribution } & \multirow[t]{2}{*}{ MW (Da) } & \multirow[t]{2}{*}{ Std Dev (Da) } & \multirow[t]{2}{*}{ MW (calc) } & \multirow[t]{2}{*}{$\Delta(\mathrm{Da})$} \\
\hline & $44+$ & $43+$ & $42+$ & $41+$ & $40+$ & $39+$ & $38+$ & & & & \\
\hline \multicolumn{12}{|l|}{ Pfnek2+ vehicle } \\
\hline 5 & 882 & 903 & 924 & 947 & 971 & 995 & 1022 & 38,784 & 0.20 & 38,784 & 0.12 \\
\hline 6 & 884 & 905 & 926 & 949 & 973 & 998 & 1024 & 38,864 & 0.72 & 38,864 & 0.31 \\
\hline 7 & 886 & 907 & 928 & 951 & 975 & 1000 & 1026 & 38,944 & 0.68 & 38,944 & 0.30 \\
\hline 8 & 888 & 909 & 930 & 953 & 977 & 1002 & 1028 & 39,024 & 0.51 & 39,024 & 0.42 \\
\hline \multicolumn{12}{|c|}{ Pfnek2+ NCL-00016066 } \\
\hline 5 & 882 & 903 & 924 & 947 & 971 & 995 & 1022 & 38,784 & 0.80 & 38,784 & 0.02 \\
\hline 6 & 884 & 905 & 926 & 949 & 973 & 998 & 1024 & 38,865 & 0.62 & 38,864 & 0.84 \\
\hline 7 & 886 & 907 & 928 & 951 & 975 & 1000 & 1026 & 38,944 & 0.75 & 38,944 & 0.43 \\
\hline 8 & 888 & 909 & 930 & 953 & 977 & 1002 & 1028 & 39,024 & 0.62 & 39,024 & 0.12 \\
\hline \multicolumn{12}{|l|}{ V24C+ vehicle } \\
\hline 5 & 883 & 903 & 924 & 947 & 971 & 995 & 1022 & 38,786 & 0.83 & 38,788 & -1.58 \\
\hline 6 & 884 & 905 & 926 & 949 & 973 & 998 & 1024 & 38,866 & 0.58 & 38,868 & -1.71 \\
\hline 7 & 886 & 907 & 928 & 951 & 975 & 1000 & 1026 & 38,946 & 1.27 & 38,948 & -1.21 \\
\hline 8 & 888 & 909 & 930 & 953 & 977 & 1002 & 1028 & 39,028 & 2.12 & 39,028 & 0.23 \\
\hline \multicolumn{12}{|c|}{ V24C+ NCL-00016066 } \\
\hline 5 & 890 & 910 & 932 & 955 & 979 & 1004 & 1030 & 39,103 & 1.77 & 38,788 & 315.30 \\
\hline 6 & 892 & 912 & 934 & 957 & 981 & 1006 & 1032 & 39,183 & 1.30 & 38,868 & 314.88 \\
\hline 7 & 893 & 914 & 936 & 959 & 983 & 1008 & 1034 & 39,262 & 1.35 & 38,948 & 314.35 \\
\hline 8 & 895 & 916 & 938 & 961 & 985 & 1010 & 1036 & 39,343 & 1.71 & 39,028 & 315.59 \\
\hline
\end{tabular}

Predicted molecular weight (Predicted MW) $=$ mass of kinase + phosphorylation sites

$\Delta(\mathrm{Da})=$ difference between predicted $\mathrm{MW}$ and measured $\mathrm{MW}$ for each charged state distribution

multiple autophosphorylation events. Analysis of tryptic phospho-peptides unequivocally identified three autophosphorylation sites, Ser20, Ser215 and Ser219 (Fig. 7). Interestingly, these autophosphorylation sites appeared to be distinct from those identified in Hsnek2 [29]. Only Ser20 is conserved in both Hsnek 2 and Pfnek-2 but is not autophosphorylated in the human [29].

\section{Discussion}

The aim of the current study was to engineer Pfnek2 in a manner that would confer sensitivity of the kinase to a kinase inhibitor that otherwise would show low levels of activity to wild type Pfnek2. This was achieved by mutating Val24 in the wild type Pfnek-2 to cysteine. This mutation confers susceptibility to the kinase inhibitor NCL-00016066, and that the nature of this inhibition is likely through an irreversible covalent link of NCL00016066 with the modified cysteine.

Pfnek-2 is expressed predominantly in female gametocytes [10]. Transmission studies with the rodent malaria parasite Plasmodium berghei showed that parasites lacking the enzyme Pfnek-2 are able to undergo gametocytogenesis, gametogenesis and fertilization, but do not develop into ookinetes; this is likely due to a defect in meiosis, as pbnek-2- $2^{-}$parasites appear to be unable to implement the pre-meiotic DNA replication that brings the DNA content to $4 \mathrm{C}$ in wild-type parasites, but remains $2 \mathrm{C}$ in the mutant parasites [10]. The demonstrated association of Pbnek-2 with microtubule-like structures in the gametocyte [10] suggests that the impairment in DNA replication may be mediated through improper spindle formation during the first round of meiotic DNA replication. Understanding the details of the molecular mechanisms that are regulated by Pfnek-2 (including identifying substrates of the enzyme) would be greatly facilitated by a model system whereby Pfnek-2 activity can be selectively and rapidly inhibited. The current study, has taken advantage of the extensive efforts to develop inhibitors to Hsnek2, considered a validated target in cancer drug discovery, to establish a chemical genetic approach to the study of Pfnek- 2 .

Structural analysis of the Hsnek2 in complex with NCL-00016066 demonstrated that this inhibitor acts in an irreversible manner by covalent linkage to cysteine 22 in the glycine rich loop. Interestingly, Pfnek-2 does not contain this cysteine, or any other cysteine, in this loop. Demonstrated here is the weak inhibitor activity of NCL00016066 against wild-type Pfnek-2 likely due to a lack of a cysteine in this position. Consistent with this notion is that NCL-00016066 showed potent inhibitory activity 


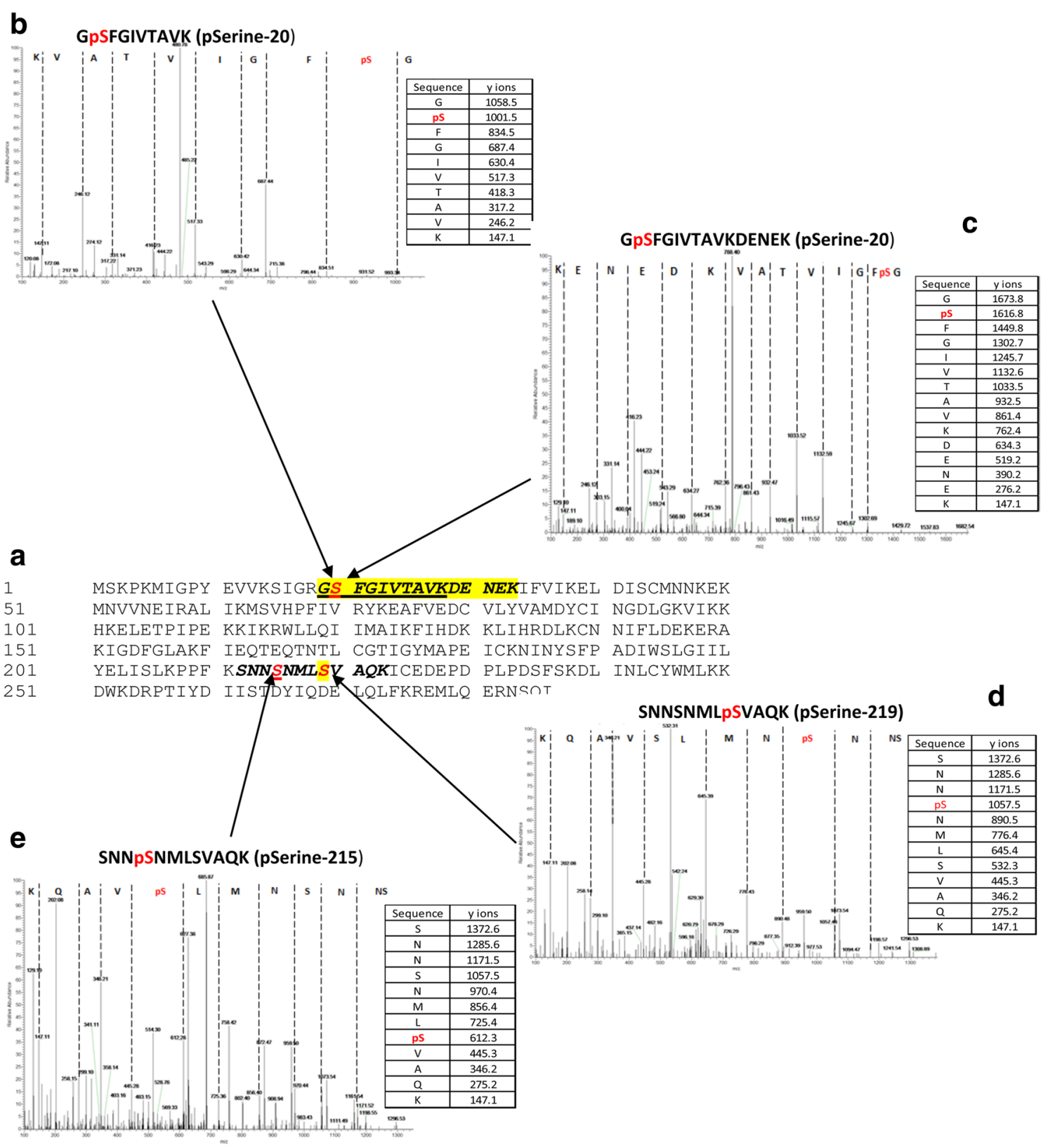

\begin{tabular}{|l|r|r|l|l|}
\hline \multicolumn{1}{|c|}{ Peptide Sequence } & $\begin{array}{l}\text { Mascot } \\
\text { lon Score }\end{array}$ & Delta PPM & $\begin{array}{l}\text { Residue } \\
\text { Number }\end{array}$ & $\begin{array}{l}\text { No of } \\
\text { times } \\
\text { observed }\end{array}$ \\
\hline (R)GSFGIVTAVK(D) & 57.19 & 0.08542 & $19-28$ & 2 \\
\hline (R)GSFGIVTAVKDENEK(I) & 85.42 & -0.9538 & $19-33$ & 3 \\
\hline (K)SNNSNMLSVAQK(I) & 91.15 & -0.2672 & $212-223$ & 1 \\
\hline (K)SNNSNMLSVAQK(I) & 73.52 & $1.6212-223$ & 1 \\
\hline
\end{tabular}

Fig. 7 Autophosphorylation sites of Pfnek-2 as determined by mass spectroscopy. a Primary amino acid sequence of Pfnek-2. Sections in bold represent Pfnek-2 peptides observed in mass spectrometry experiments and in red are amino acids identified as being phosphorylated. b-e Representative mass spectra and associated fragmentation tables are shown that cover the three identified phosphorylated residues (Ser-20, Ser-215, and Ser-219). $\mathbf{f}$ List of the phospho-peptides identified in the overall data set 
if a cysteine residue is introduced into the glycine-rich loop of Pfnek-2. Furthermore, this inhibition appeared to be irreversible, and mass spectrometry studies indicated that this is likely due to covalent modification of the variant kinase at the substituted cysteine.

\section{Conclusions}

Recent studies have deployed a chemical genetic approach to the study of PfPKG where parasites expressing a mutant form of the kinase that is resistant to inhibition by a selective PfPKG inhibitor was used to identify cellular targets and physiological roles of the kinase [28]. The engineering described here of a variant of Pfnek-2 that can impart sensitivity to chemical inhibition now allows for a similar chemical genetic strategy for the study of Pfnek-2. In this instance, the introduction of the Pfnek-2(V24C) mutant into the gene locus of Pfnek-2 will generate a mutant parasite strain that expresses a variant of Pfnek- 2 sensitive to inhibition by NCL-00016066. In this way NCL-00016066 can be used as a selective probe to define the cellular targets and physiological role of this kinase. Importantly NCL-00016066 will likely be selective for the engineered mutant parasite as there are no cysteine residues in the glycine rich loop of any of the other Pfneks.

In this way, the data presented here opens the door to investigating the essential role that Pfnek-2 plays in the transmission of malaria from the host to the mosquito vector and in doing so might inform on the mode of action of potential transmission-blocking drugs targeting this kinase.

\section{Abbreviations}

ACT: artemisinin-based combination therapy; MBP: myelin basic protein; Nek: NIMA-related kinase; NIMA: never in mitosis/Aspergillus; NTA: nitriloacetic acid; WHO: World Health Organization.

\section{Authors' contributions \\ DFM was involved in the study design, carried out the laboratory work, organized and analysed the data, drafted and revised the manuscript. ARB was involved in mass spectrometry work and analysis. KC was involved in plasmid design. CRC, CC, BTG, RB and RJG were involved in the design and synthesis of NCL-00016066 and human nek2 studies. RB provided the X-ray crystal structure of NCL-00016066 bound to human Nek2. CRC, CC, RB, AMF, CD and $A B T$ were all involved in revising the manuscript. ABT was also involved in the design, interpretation and revisions of the manuscript. All authors read and approved the final manuscript.}

\footnotetext{
Author details

${ }^{1}$ Department of Molecular and Cell Biology, University of Leicester, Lancaster Road, Leicester LE1 9HN, UK. ${ }^{2}$ Protein and Nucleic Acid Chemistry Laboratory, University of Leicester, Hodgkin Building, Leicester LE1 9HN, UK. ${ }^{3}$ School of Pharmacy and Biomolecular Sciences, Liverpool John Moores University, 2 Rodney Street, Liverpool L3 5UX, UK. ${ }^{4}$ School of Chemistry, Bedson Building, Northern Institute for Cancer Research, Newcastle University, Newcastle upon Tyne NE1 7RU, UK. ${ }^{5}$ Department of Microbiology, Building 76, Monash University, Wellington Road, Clayton, VIC 3800, Australia. ${ }^{6}$ Astbury 6.108a, School of Molecular and Cellular Biology, University of Leeds, Leeds LS2 9JT, UK.
}

${ }^{7}$ Centre for Translational Pharmacology, Institute of Molecular Cell and Systems Biology, University of Glasgow, Glasgow G12 8QQ, UK.

\section{Acknowledgements}

ABT was supported by a programme grant through the MRC Toxicology Unit. DFM is a Daphne Jackson Research Fellow funded by the BBSRC and the University of Leicester. CRC was supported by Cancer Research UK.

\section{Competing interests}

The authors declare that they have no competing interests.

\section{Availability of data and material}

All data and materials presented in this article are freely available by contact with the corresponding author.

\section{Consent for publication}

All the authors have commented on the manuscript and consented to submission and publication.

\section{Ethics approval and consent to participate}

The experiments described here do not require ethical approval. All the authors have been consulted about the experiments and consented to participate in the study and publication of results.

Received: 28 May 2016 Accepted: 28 October 2016

Published online: 07 November 2016

\section{References}

1. WHO. World Malaria Report 2015. Geneva: World Health Organization; 2015:280.

2. Noedl H, Se Y, Schaecher K, Smith BL, Socheat D, Fukuda MM. Evidence of artemisinin-resistant malaria in western Cambodia. N Engl J Med. 2008:359:2619-20.

3. Phyo AP, Nkhoma S, Stepniewska K, Ashley EA, Nair S, McGready R, et al. Emergence of artemisinin-resistant malaria on the western border of Thailand: a longitudinal study. Lancet. 2012;379:1960-6.

4. Dondorp AM, Nosten F, Poravuth Y, Das D, Phyo AP, Tarning J, et al. Artemisinin resistance in Plasmodium falciparum malaria. Drug Therapy. 2009:361:455-67.

5. Solyakov L, Halbert J, Alam MM, Semblat J-P, Dorin-Semblat D, Reininger $L$, et al. Global kinomic and phospho-proteomic analyses of the human malaria parasite Plasmodium falciparum. Nat Commun. 2011;2:565.

6. Doerig C, Billker O, Haystead T, Sharma P, Tobin AB, Waters NC. Protein kinases of malaria parasites: an update. Trends Parasitol. 2008:24:570-7.

7. Zuccotto F, Ardini E, Casale E, Angiolini M. Through the "gatekeeper door": exploiting the active kinase conformation. J Med Chem. 2010:53:2681-94.

8. Reininger L, Billker O, Tewari R, Mukhopadhyay A, Fennell C, Dorin-Semblat $\mathrm{D}$, et al. A NIMA-related protein kinase is essential for completion of the sexual cycle of malaria parasites. J Biol Chem. 2005;280:31957-64.

9. Reininger L, Tewari R, Fennell C, Holland Z, Goldring D, Ranford-Cartwright $L$, et al. An essential role for the Plasmodium Nek-2 Nima-related protein kinase in the sexual development of malaria parasites. J Biol Chem. 2009;284:20858-68.

10. Dorin-Semblat D, Schmitt S, Semblat JP, Sicard A, Reininger L, Goldring D, et al. Plasmodium falciparum NIMA-related kinase Pfnek-1: sex specificity and assessment of essentiality for the erythrocytic asexual cycle. Microbiology. 2011;157:2785-94.

11. Reininger L, Garcia M, Tomlins A, Muller S, Doerig C. The Plasmodium falciparum, Nima-related kinase Pfnek-4: a marker for asexual parasites committed to sexual differentiation. Malar J. 2012;11:250

12. Dorin D, Le Roch K, Sallicandro P, Alano P, Parzy D, Poullet P, et al. Pfnek-1, a NIMA-related kinase from the human malaria parasite Plasmodium falciparum. Eur J Biochem. 2001;268:2600-8.

13. Fry AM, O'Regan L, Sabir SR, Bayliss R. Cell cycle regulation by the NEK family of protein kinases. J Cell Sci. 2012;125:4423-33.

14. Hayward DG, Newbatt Y, Pickard L, Byrne E, Mao G, Burns S, et al. Identification by high-throughput screening of viridin analogs as biochemical 
and cell-based inhibitors of the cell cycle-regulated nek2 kinase. J Biomol Screen. 2010;15:918-27.

15. Hayward DG, Clarke RB, Faragher AJ, Pillai MR, Hagan IM, Fry AM. The centrosomal kinase Nek2 displays elevated levels of protein expression in human breast cancer. Cancer Res. 2004;64:7370-6.

16. Hayward DG, Fry AM. Nek2 kinase in chromosome instability and cancer. Cancer Lett. 2006;237:155-66.

17. O'Regan L, Blot J, Fry AM. Mitotic regulation by NIMA-related kinases. Cell Div. 2007;2:25

18. Kokuryo T, Senga T, Yokoyama Y, Nagino M, Nimura Y, Hamaguchi M. Nek2 as an effective target for inhibition of tumorigenic growth and peritoneal dissemination of cholangiocarcinoma. Cancer Res. 2007;67:9637-42.

19. Tsunoda N, Kokuryo T, Oda K, Senga T, Yokoyama Y, Nagino M, et al. Nek2 as a novel molecular target for the treatment of breast carcinoma. Cancer Sci. 2009;100:111-6.

20. Whelligan DK, Solanki S, Taylor D, Thomson DW, Cheung KMJ, Boxall K, et al. Aminopyrazine inhibitors binding to an unusual inactive conformation of the mitotic kinase Nek2: SAR and structural characterization. J Med Chem. 2010;53:7682-98.

21. Westwood I, Cheary DM, Baxter JE, Richards MW, van Montfort RLM, Fry $\mathrm{AM}$, et al. Insights into the Conformational Variability and Regulation of Human Nek2 Kinase. J Mol Biol. 2009;386:476-85.

22. Solanki S, Innocenti P, Mas-Droux C, Boxall K, Barillari C, Van Montfort RLM, et al. Benzimidazole inhibitors induce a DFG-out conformation of never in mitosis gene a-related kinase 2 (Nek2) without binding to the back pocket and reveal a nonlinear structure-activity relationship. J Med Chem. 2011;54:1626-39.

23. Richards MW, O'Regan L, Mas-Droux C, Blot JMY, Cheung J, Hoelder S, et al. An autoinhibitory tyrosine motif in the cell-cycle-regulated Nek7 kinase is released through binding of Nek9. Mol Cell. 2009;36:560-70.

24. Lebraud H, Coxon CR, Archard VS, Bawn CM, Carbain B, Matheson CJ, et al. Model system for irreversible inhibition of Nek2: thiol addition to ethynylpurines and related substituted heterocycles. Org Biomol Chem. 2013;12:141-8

25. Trager W, Jensen JB. Human malaria parasites in continuous culture. Science. 1976;193:673-5.

26. Lambros C, Vanderberg JP. Synchronization of Plasmodium falciparum erythrocytic stages in culture. J Parasitol. 1979;65:418-20.

27. Winkler R. ESI prot: a universal tool for charge state determination and molecular weight calculation of proteins from electrospray ionization mass spectrometry data. Rapid Commun Mass Spectrom. 2010;24:285-94.

28. Alam MM, Solyakov L, Bottrill AR, Flueck C, Siddiqui FA, Singh S, et al. Phosphoproteomics reveals malaria parasite Protein Kinase $\mathrm{G}$ as a signalling hub regulating egress and invasion. Nat. Commun. 2015;6:7285.

29. Rellos P, Ivins FJ, Baxter JE, Pike A, Nott TJ, Parkinson DM, et al. Structure and regulation of the human Nek2 centrosomal kinase. J Biol Chem. 2007:282:6833-42.

\section{Submit your next manuscript to BioMed Central and we will help you at every step:}

- We accept pre-submission inquiries

- Our selector tool helps you to find the most relevant journal

- We provide round the clock customer support

- Convenient online submission

- Thorough peer review

- Inclusion in PubMed and all major indexing services

- Maximum visibility for your research

Submit your manuscript at www.biomedcentral.com/submit 